\title{
Ten Year Yield Response of Beardless Wheatgrass from a Single Nitrogen Application ${ }^{1}$
}

\section{J. L. MASON AND J. E. MILTIMORE ${ }^{2}$}

Head, Soil Science Section, and Head, Animal Science Section,$^{3}$ Research Station, Canada Department of Agriculture, Summerland, British Columbia.

\section{Highlight}

Forage yields were measured from 1959 to 1968 in response to a single fertilizer application in the fall of 1958 in southern British Columbia. The ten-year accumulated forage yield of beardless wheatgrass increased from 3000 pounds per acre at zero nitrogen treatment to 7750 pound per acre at 450 pounds per acre nitrogen treatment. Yield response from the lower application rates was greatest in the earlier years of the experiment. The general yield levels declined in the later years of the experiment. Nitrogen concentration in plant tops increased from 0.7 percent at the zero application level to 1.5 percent at the 450 pound application level in the first year. Nitrogen concentration gradually declined over the first eight years at the higher application rates. By the last two years, there was no effect remaining of treatment on nitrogen accumulation. Plant analyses for $\mathrm{Ca}, \mathrm{K}, \mathrm{Mg}, \mathrm{Zn}, \mathrm{Mn}$ and $\mathrm{Fe}$ showed sharp declines in $\mathrm{Ca}$ and $\mathrm{Zn}$ but only minor changes in other elements from increasing nitrogen application levels. Plant crown diameter had increased from 4.4 to 5.2 inches with increasing nitrogen rates by the fifth year of the experiment.

The forage yield response of native range grasses to nitrogen fertilizer in the interior areas of northwest United States and southwest Canada has been well documented in recent years. Yield increases up to two and three times the check have been recorded (Hubbard and Mason, 1967; Kilcher et al., 1965; Johnston et al., 1968; Mason and Miltimore, 1959, 1964, 1969; Rogler and Lorenz, 1957; Sneva et al., 1958). Considerable increase in seed production as a result of nitrogen fertilization has also been reported (Miltimore et al., 1962).

Most of the literature records relatively short-term responses up to approximately three years. The experiment reported in this paper was carried on for ten years after a single nitrogen fertilizer application.

${ }^{1}$ Contribution No. 325. Received July $19,1971$.

${ }^{2}$ Acknowledgments. The authors are most grateful for the devoted assistance of L. Uzick, J. Brown, J. McDougald and B. Drought.

${ }^{3}$ Now Director, Research Station, Canada Department of Agriculture, Kamloops, B.C.
Yield and nitrogen analysis data for the 10 years are presented. Mineral analysis data for 2 years is also presented.

\section{Materials and Methods}

The experiment was laid out on a terrace near the southern end of Okanagan Lake, British Columbia. The soil type is Penticton silt loam, a Brown soil, and the natural cover is an association of beardless wheatgrass (Agropyron inerme (Scrib. and Smith) Rydb.), Sandberg bluegrass (Poa secunda), and big sagebrush (Artemisia tridentata). The test area was mown close to ground level with a heavy-duty rotary mower to remove the sagebrush before the plots were established. The area had not been grazed for several years and was not grazed during the test period.

Precipitation at the weather station of the Research Station, Summerland, located about one mile from the plots has averaged 10.99 inches over 52 years and is fairly evenly distributed from month to month. Elevation of the site is about 1300 feet above sea level.
The experimental design was a randomized complete block with 12 treatment levels and 10 replications. A single application of nitrogen fertilizer was applied to the plots as commercial ammonium nitrate fertilizer (33.5-0-0) in late November, 1958. The twelve rates of application were: $0,25,50,75,100$, $150,200,250,300,350,400,450$ pounds of actual nitrogen per acre. Plots were 8 by 20 feet. A strip 36 inches wide by 20 feet long was harvested through the conter of each plot in the same place each year for the ten years the experiment was carried on. Harvesting was done close to the seed-set stage of maturity. The total harvest from each plot was oven-dried at $95 \mathrm{C}$ and the weight recorded. The oven-dried grass was ground in a Wiley mill and thoroughly mixed in an endover-end tumbler box. Nitrogen was determined by the A.O.A.C. microkjeldahl method (A.O.A.C., 1955) and $\mathrm{Ca}, \mathrm{K}, \mathrm{Mg}, \mathrm{Zn}, \mathrm{Mn}$ and Fe by atomic absorption spectrophotometry.

Plant diameters were measured by pushing a thin steel desk ruler horizontally through the plant just above the crown. The diameter was then read from the bottom edge of the ruler.

\section{Results}

The accumulated dry matter yield of grass was increased by all rates of nitrogen fertilizer. From 1959 to 1963 , the yield was approximately doubled by the highest nitrogen level as compared to the yield from the check treatment. In 1962 all yields were low but nevertheless the highest nitrogen application rate still produced twice the yield of the check (Fig. 1).

From 1964 to 1968, yields were still approximately doubled by the highest nitrogen application when compared to the check treatment. However, there was a continuous decline in overall yield throughout this period. At the beginning of the period, the highest rates were producing about 1000 pounds per acre and at the end of the period 




Fic. 1. Yield of beardless wheatgrass from 1959 to 1968 in response to a single application of nitrogen fertilizer in 1958.

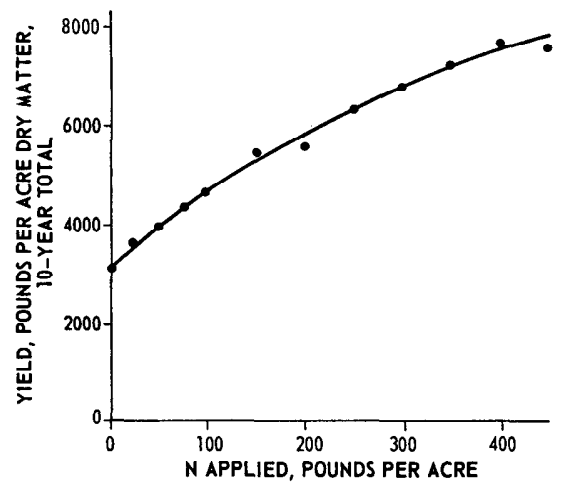

FIG. 2. Total yield of beardless wheatgrass during the period 1959 to 1968 from a single application of nitrogen fertilizer in 1958.

only about $500 \mathrm{lb}$./acre. Similarly, at the beginning of the period, the check treatment was producing about $450 \mathrm{lb}$./acre but at the end of the period only about $275 \mathrm{lb}$./ acre. Analysis of variance showed highly significant differences $(\mathbf{P}=$ 0.01 ) in all years between yield and $\mathrm{N}$ rates.

The total yield for the ten year period was $7,750 \mathrm{lb}$./acre at the highest nitrogen level as compared to 3,000 at the zero nitrogen level. This is $255 \%$ of the zero nitrogen yicld (Fig. 2).

The response curve for total yield over the ten year period is almost linear (Fig. 2). However, the curves for the individual years show a gradual change in the shape of the curve with time. Yields at the lower nitrogen applications of 0 to 200 pounds per acre increase sharply at the beginning of the period but the increase becomes considerably less sharp towards the end of the period (Fig. 1).

Nitrogen concentration in the harvested forage ranged from $0.7 \%$ at the zero nitrogen rate to $1.5 \%$ at the $450-1 b$. nitrogen rate in the first year of the experiment (Fig. 3). Differences between treatments gradually reduced each year until 1966, the eighth year of the experiment. In 1967 and 1968, the last two years, there was no change in nitrogen concentration due to treatment. Analysis of variance showed highly significant differences $(P=$ $0.01)$ for nitrogen concentration in the harvested forage resulting from different nitrogen application rates for all years except 1967 and 1968 .

Analyses of the harvested forage carried out on the 1967 and 1968

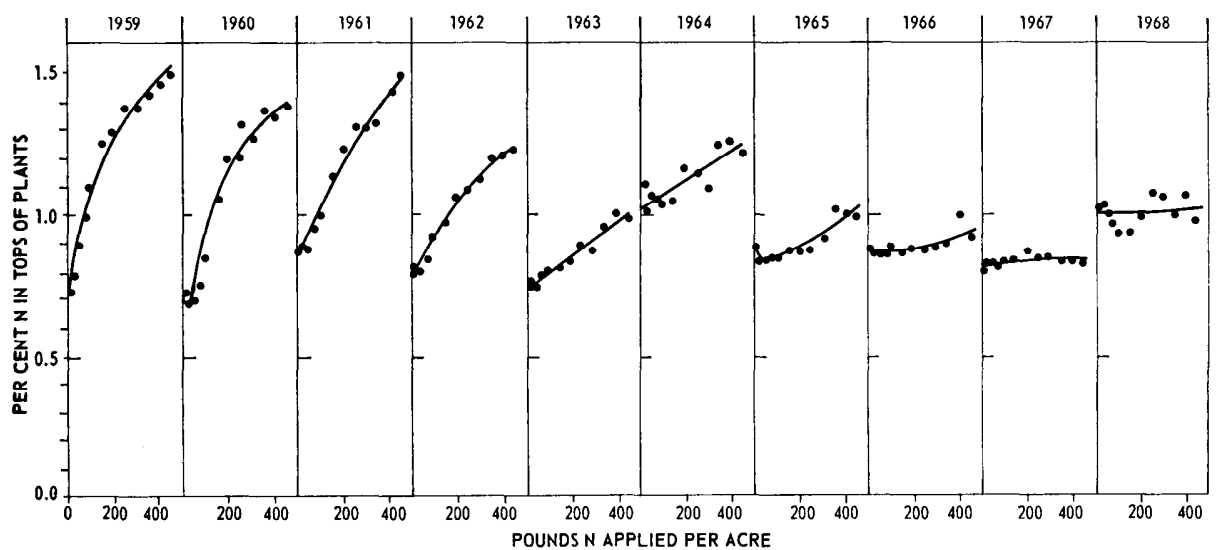

FIG. 3. Effect of a single application of nitrogen fertilizer in 1958, on nitrogen concentration in beardless wheatgrass for succeeding 10 years. 


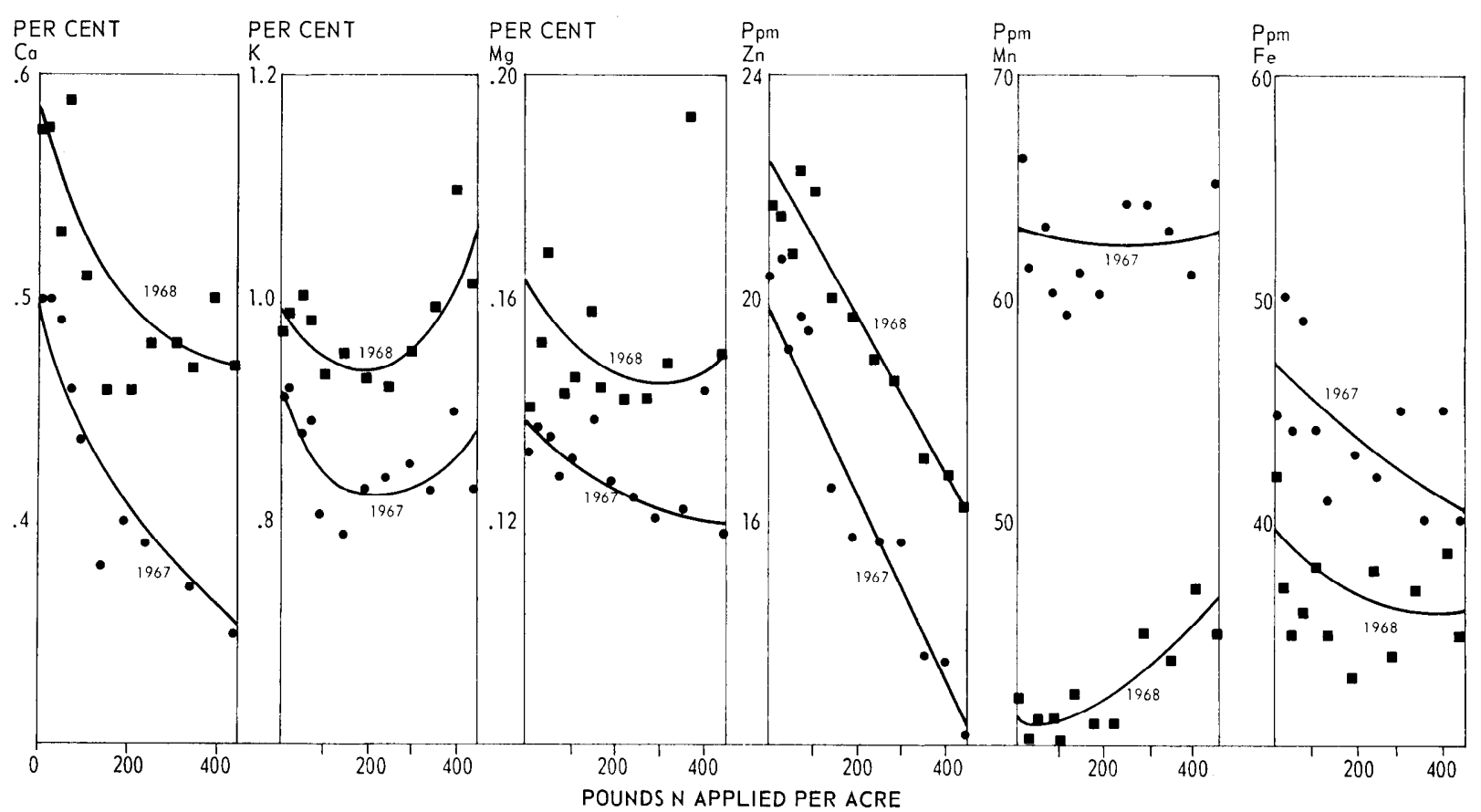

Fic. 4. Concentration of the mineral nutrients in beardless wheatgrass in 1967 and 1968 as affectcd by a single nitrogen application in 1958.

harvested material showed that calcium was reduced with increasing nitrogen application levels. In 1968, the forage from the zero nitrogen treatment contained about $0.58 \%$ calcium, but the forage from the $450 \mathrm{lb}$. of nitrogen treatment contained only $0.47 \%$. In 1967 , the two comparable figures were 0.50 and 0.35. Potassium concentration was not affected by the low and high nitrogen treatments, but the middle treatments caused a small reduction. Magnesium was reduced slightly with the higher nitrogen applications. Zinc was greatly reduced by the higher nitrogen rates. In 1968 it was reduced from 22 to $16 \mathrm{ppm}$ from the lowest to the highest treatment. In 1967 it was reduced from 20 to $12 \mathrm{ppm}$. Manganesc conccntration was unaffected by nitrogen application rate in 1967 and was only slightly increased in 1968 . Iron was reduced from 47 to $41 \mathrm{ppm}$ in 1967 and from 40 to $36 \mathrm{ppm}$ in 1968 as nitrogen rates increased from 0 to 450 pounds per acre (Fig. 4).

Plant size, measured as diameter of the crown in 1963, showed an increase from about 4.4 inches at the zero nitrogen level to about 5.2

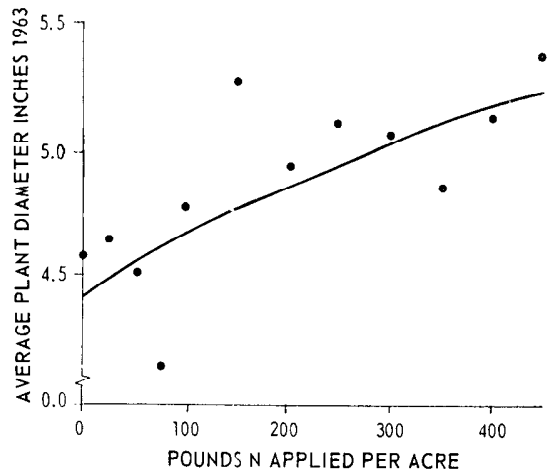

FIG. 5. Average diameter of plant crowns measured in 1963 in relation to nitrogen fertilizer rates.

inches at the $450 \mathrm{lb}$. nitrogen application level (Fig. 5).

\section{Discussion}

The results show that very considerable increases in yield of native grassland can be obtained for a period of ten years from a single nitrogen fertilizer application under the conditions of this experiment. Even in the tenth year after application of the fertilizer, there was still a large yield increase with the highest nitrogen application rate producing 2.2 times the zero rate. There appear to be good prospects of higher yields for several more years. These results show that long-term yield increases can be obtained from a single fertilizer application at least under the conditions of this experiment. Work reported before has shown yield increases usually for 2 or 3 years following a fertilizer application (Hubbard and Mason, 1967; Kilcher et al., 1965; Johnston et al., 1968; Mason and Miltimore, 1959, 1964, 1969; Rogler and Lorenz, 1957; Sneva et al., 1958). Long-term yield increase from a single fertilizer application can be expected to have marked beneficial effects on the economics of fertilizer application to range grasses.

The gradual decline in the general level of yield in the last five years of the experiment is probably related to the extreme harvesting technique practiced. Each year, the same strip of grass was mowed to the usual cutter-bar height at the time of seed-set. This treatment may exert considerable stress on grass plants. Under less rigorous normal grazing where only $50 \%$ of the tops are removed, such a decline would be less likely to occur. 


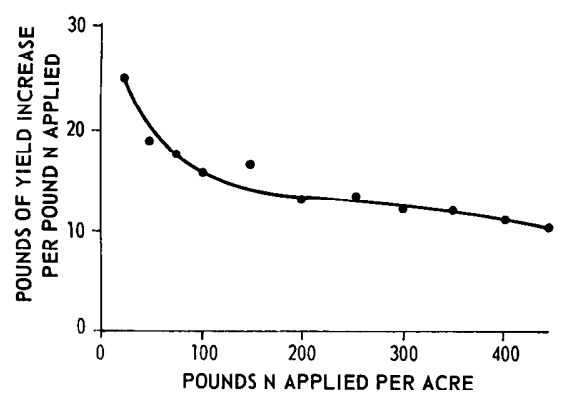

FIs. 6. Pounds of yield increase obtained per pound of nitrogen fertilizer applied for each of the nitrogen application rates used.

The lowest rate of nitrogen application (25 lb./acre) was the most efficient producing $25 \mathrm{lb}$. of forage for each pound of nitrogen applied (Fig. 6). At the 100 lb. nitrogen application rate, the yield increase had dropped to $16 \mathrm{lb}$. of forage per pound of nitrogen applied. At the 350-1b. rate, the yield increase was reduced to $12 \mathrm{lb}$. and at the $450-\mathrm{lb}$. level, it was further reduced to 10 pounds. The lowest application rate therefore gave the highest returns in pounds of forage per pound of nitrogen applied. Full economic evaluation would need to include further cost factors such as fixed cost of fertilizer application, variable costs of transporting fertilizer to the application site, and cost per pound of nitrogen. These would all vary with each proposal evaluated.

The nitrogen concentration in the harvested forage was not affected by nitrogen fertilizer application rate in the last two years, 1967 and 1968 (Fig. 3). However, considerable yield increases were still being obtained in these two years (Fig. 1). The average yield increase in the last two years was $139 \%$ from the zero treatment to the $450-1 \mathrm{~b}$. treatment. There was obviously some improvement in the plants which was not reflected in the nitrogen concentration in the forage. One improvement which could very well be associated with higher yield is plant size. A measure of plant size, the diameter of the crown, was taken in 1963. Diameter increased from 4.4 to 5.4 inches or $23 \%$ with increasing nitrogen rates from 0 to $450 \mathrm{lb}$ /acre. This is much less than the yield increases of $139 \%$. Diameter of the crown can be used as a base for a measure of root volume. Calculations of spherical, conical and cylindrical volume show that a cylinder having a height equal to the square of the radius has a volume increase of approximately the same percentage as the yield increase, $144 \%$.

The reduced $\mathrm{Ca}$ and $\mathrm{Mg}$ levels in the forage would be critical if the trend were to continue, though the lowest levels recorded are above the minimum levels required for most classes of ruminants. Zn levels are well below the accepted requirements of ruminants and the use of increased $\mathrm{Zn}$ supplementation becomes essential with the higher levels of $\mathrm{N}$ fertilization.

The practical use of these findings for the ranches is a thorny economic problem. Despite the large increases in yield possible from modest applications of nitrogen fertilizer, the ranchers make virtually no use of this practice, and technical range advisors do not recommend it as a general practice although they do make very limited recommendations for using it to guide cattle to desired locations.

The method of application of fertilizer is also a great challenge to the rancher. In New Zealand, large tonnages of fertilizer have been flown on to range in rough terrain. This would seem to be the preferred method in mountainous or rough terrain. However, a large acreage of land is needed as well as specialized high-speed loading equipment to keep costs down.

There does not appear to be much immediate practical potential for the findings reported in this paper.

\section{Literature Cited}

Association of Official Agricultural Chemists. 1955. Official methods of analysis. 8th Ed. Washington, D.C.

Hubbard, W. A., and J. L. Mason. 1967. Residual effects of ammonium nitrate and ammonium phosphate on native ranges of British Columbia. J. Range Manage. 20:1-5.

Kilcher, M. R., S. Smoliak, W. A. Hubbard, A. Johnston, A. T. H. Gross, AND E. V. MCCurdy. 1965. Effects of inorganic nitrogen and phosphorus fertilizers on selected sites of native grassland in Western Canada. Can. J. Plant Sci. 45:229237.

Johnston, A., A. D. Smith, L. E. LutWICK, AND S. SMoliak. 1968. Fertilizer response of native and seeded ranges. Can. J. Plant Sci. 48:467-472.

MADER, E. L. 1967. The influence of certain fertilizer treatments on the native vegetation of Kansas prairie. Diss. Abstr. 17:209-210.

Mason, J. L., AND J. E. Miltimore. 1959. Increase in yield and protein content of native bluebunch wheatgrass from nitrogen fertilization. Can. J. Plant Sci. 39:501-504.

Mason, J. L., and J. E. Miltimore. 1964. Effect of nitrogen content of beardless wheatgrass on yield response to nitrogen fertilization. J. Range Manage. 17:145-147.

Mason, J. L. and J. E. Miltimore. 1969. Yield increases from nitrogen on native rangc in southcrn British Columbia. J. Range Manage. 22: 128-131.

Miltimore, J. E., J. L. Mason, and C. B. W. Rogers. 1962. Increase in seed production from nitrogen fertilization of native beardless wheatgrass. Can. J. Plant Sci. 42:359-364.

Rogler, G. A., AND R. J. LORENZ. 1957. Nitrogen fertilization of Northern Great Plains rangelands. J. Range Manage. 10:156-160.

Sneva, F. E., D. N. Hyder, and C. S. CoOprer. 1958. The influence of ammonium nitrate on the growth and yield of crested wheatgrass on the Oregon high desert. Agron. J. $50: 40-44$. 